\title{
Creative Accounting Practices at Satyam Computers Limited: A Case Study of India's Enron
}

\author{
Madan Lal Bhasin ${ }^{1}$
}

\begin{abstract}
Satyam Computers were once the crown jewel of Indian IT industry, however, the debacle of Satyam raised a debate about the role of CEO in driving a company to the heights of success and its relation with the board members and core committees. The scam brought to the light the role of corporate governance (CG) in shaping the protocols related to the working of audit committees and duties of board members. The Satyam scam was a jolt to the market, especially to Satyam stockholders. This paper attempts an in-depth analysis of India's Enron, Satyam Computer's "creative-accounting" scandal. In public companies, this type of 'creative' accounting leading to fraud and investigations are, therefore, launched by the various governmental oversight agencies. The accounting fraud committed by the founders of Satyam in 2009 is a testament to the fact that "the science of conduct is swayed in large by human greed, ambition, and hunger for power, money, fame and glory." Scandals have proved that "there is an urgent need for good conduct based on strong corporate governance, ethics and accounting \& auditing standards." The Satyam scandal highlights the importance of securities laws and CG in emerging markets. Indeed, Satyam fraud "spurred the government of India to tighten the CG norms to prevent recurrence of similar frauds in future." Thus, major financial reporting frauds need to be studied for 'lessons-learned' and 'strategies-to-follow' to reduce the incidents of such frauds in the future. The increasing rate of white-collar crimes "demands stiff penalties, exemplary punishments, and effective enforcement of law with the right spirit."
\end{abstract}

Keywords: Accounting scandal, accounting and auditing standards, Creative accounting practices.

Available Online: 28-06-2016

This is an open access article under Creative Commons Attribution 4.0 License, 2016.

\section{$1.0 \quad$ INTRODUCTION}

Fraud is a worldwide phenomenon that affects all continents and all sectors of the economy. Fraud encompasses a wide-range of illicit practices and illegal acts involving intentional deception or misrepresentation. According to the Association of Certified Fraud Examiners (ACFE, 2010), fraud is "a deception or misrepresentation that an individual or entity makes knowing that misrepresentation could

\footnotetext{
${ }^{1}$ Professor, School of Accountancy, College of Business, Universiti Utara Malaysia, Sintok, Kedah Darul Aman, Malaysia. E-mail: madan.bhasin@rediffmail.com
} 
result in some unauthorized benefit to the individual or to the entity or some other party." In other words, mistakes are not fraud. Indeed, in fraud, groups of unscrupulous individuals manipulate, or influence the activities of a target business with the intention of making money, or obtaining goods through illegal or unfair means. Fraud cheats the target organization of its legitimate income and results in a loss of goods, money, and even goodwill and reputation. Fraud often employs illegal and immoral, or unfair means.

Organizations of all types and sizes are subject to fraud. On a number of occasions over the past few decades, major public companies have experienced financial reporting fraud, resulting in turmoil in the U.S. capital markets, a loss of shareholder value, and, in some cases, the bankruptcy of the company itself. Although it is generally accepted that the Sarbanes-Oxley Act has improved corporate governance and decreased the incidence of fraud, recent studies and surveys indicate that investors and management continue to have concerns about financial statement fraud. For example, the Association of Certified Fraud Examiners' (ACFE) "2010 Report to the Nations on Occupational Fraud and Abuse" found that financial statement fraud, while representing less than $5 \%$ of the cases of fraud in its report, was by far the most costly, with a median loss of $\$ 1.7$ million per incident. Survey participants estimated that the typical organization loses $5 \%$ of its revenues to fraud each year. Applied to the 2011 Gross World Product, this figure translates to a potential projected annual fraud loss of more than $\$ 3.5$ trillion. The median loss caused by the occupational fraud cases in our study was $\$ 140,000$. More than one-fifth of these cases caused losses of at least $\$ 1$ million. The frauds reported to us lasted a median of 18 months before being detected.

While many changes in financial audit processes have stemmed from financial fraud or manipulations, history and related research repeatedly demonstrates that a financial audit simply cannot be relied upon to detect fraud at any significant level. The ACFE conducts research on fraud and provides a report on the results biennially, entitled "Report to the Nation." The statistics in these reports consistently states that about $10-12 \%$ of all detected frauds are discovered by financial auditors. The KPMG Fraud Survey consistently reports 4 to $12 \%$ but substantively similar detection rates. The dismal reliability of financial audits to detect fraud can be explained very simply. They are not designed or executed to detect frauds.

\subsection{CONSEQUENCES OF FRAUDULENT FINANCIAL REPORTING}

Fraudulent financial reporting can have significant consequences for the organization and its stakeholders, as well as for public confidence in the capital markets. Periodic high-profile cases of fraudulent financial reporting also raise concerns about the credibility of the U.S. financial reporting process and call into question the roles of management, auditors, regulators, and analysts, among others (Telberg, 2003).

Moreover, fraud impacts organizations in several areas: financial, operational and psychological. While the monetary loss owing to fraud is significant, the full impact of fraud on an organization can be staggering. In fact, the losses to reputation, goodwill, and customer relations can be devastating. When fraudulent financial reporting occurs, serious consequences ensue. The damage that results is also widespread, with a sometimes devastating 'ripple' effect. Those affected may range from the 'immediate' victims (the company's stockholders and creditors) to the more 'remote' (those harmed when investor confidence in the stock market is shaken). Between these two extremes, many others may be affected: 'employees' who suffer job loss or diminished pension fund value; 'depositors' in financial institutions; the company's 'underwriters, auditors, attorneys, and insurers'; and even honest 'competitors' whose reputations suffer by association. As fraud can be perpetrated by any employee within an organization or by those from the outside, therefore, it is important to have an effective "fraud management" program in place to safeguard your organization's assets and reputation. Thus, prevention and earlier detection of fraudulent financial reporting must start with the entity that prepares financial reports. 
The wave of financial scandals at the turn of the 21st century elevated the awareness of fraud and the auditor's responsibilities for detecting it. The frequency of financial statement fraud has not seemed to decline since the passage of the Sarbanes-Oxley Act in July 2002 (Hogan et al., 2008). For example, The $4^{\text {th }}$ Biennial Global Economic Crime Survey (2007) of more than 3,000 corporate officers in 34 countries conducted by PricewaterhouseCoopers (PWC) reveals that "in the post-Sarbanes-Oxley era, more financial statement frauds have been discovered and reported, as evidenced by a $140 \%$ increase in the discovered number of financial misrepresentations (from 10\% of companies reporting financial misrepresentation in the 2003 survey to $24 \%$ in the 2005 survey). The increase in fraud discoveries may be due to an increase in the amount of fraud being committed and/or also due to more stringent controls and risk management systems being implemented," (PricewaterhouseCoopers 2005). The high incidence of fraud is a serious concern for investors as fraudulent financial reports can have a substantial negative impact on a company's existence as well as market value. For instance, the lost market capitalization of 30 high-profile financial scandals caused by fraud from 1997 to 2004 is more than $\$ 900$ billion, which represents a loss of $77 \%$ of market value for these firms, while recognizing that the initial market values were likely inflated as a result of the financial statement fraud.

No doubt, recent corporate accounting scandals and the resultant outcry for transparency and honesty in reporting have given rise to two disparate yet logical outcomes. First, 'forensic' accounting skills have become crucial in untangling the complicated accounting manoeuvres that have obfuscated financial statements. Second, public demand for change and subsequent regulatory action has transformed 'corporate governance' (henceforth, CG) scenario. Therefore, more and more company officers and directors are under ethical and legal scrutiny. In fact, both these trends have "the common goal of addressing the investors' concerns about the transparent financial reporting system." The failure of the corporate communication structure has made the financial community realize that there is a great need for 'skilled' professionals that can identify, expose, and prevent 'structural' weaknesses in three key areas: poor CG, flawed internal controls, and fraudulent financial statements. "Forensic accounting skills are becoming increasingly relied upon within a corporate reporting system that emphasizes its accountability and responsibility to stakeholders" (Bhasin, 2008). Following the legislative and regulatory reforms of corporate America, resulting from the Sarbanes-Oxley Act of 2002, reforms were also initiated worldwide. Largely in response to the Enron and WorldCom scandals, Congress passed the SarbanesOxley Act (SOX) in July 2002. SOX, in part, sought to provide whistle-blowers greater legal protection. As Bowen et al. (2010) states, "Notable anecdotal evidence suggests that whistle-blowers can make a difference. For example, two whistle-blowers, Cynthia Cooper and Sherron Watkins, played significant roles in exposing accounting frauds at WorldCom and Enron, respectively, and were named as the 2002 persons of the year by Time magazine."

Given the current state of the economy and recent corporate scandals, fraud is still a top concern for corporate executives. In fact, the sweeping regulations of Sarbanes-Oxley, designed to help prevent and detect corporate fraud, have exposed fraudulent practices that previously may have gone undetected. Additionally, more corporate executives are paying fines and serving prison time than ever before. No industry is immune to fraudulent situations and the negative publicity that swirls around them. The implications for management are clear: every organization is vulnerable to fraud, and managers must know how to detect it, or at least, when to suspect it.

\subsection{REVIEW OF LITERATURE}

Starting in the late 1990s, a wave of corporate frauds in the United States occurred with Enron's failure perhaps being the emblematic example. Jeffords (1992) examined 910 cases of frauds submitted to the "Internal Auditor" during the nine-year period from 1981 to 1989 to assess the specific risk factors cited in the Treadway Commission Report. He concluded that "approximately 63\% of the 910 fraud cases are classified under the internal control risks." However, Calderon and Green (1994) made an analysis of 114 actual cases of corporate fraud published in the "Internal Auditor" during 1986 to 1990. They found that limited separation of duties, false documentation, and inadequate (or non-existent) control accounted for $60 \%$ of the fraud cases. Moreover, the study found that professional and managerial employees were involved in $45 \%$ of the cases. In addition, Smith (1995) offered a 'typology' of individuals who embezzle. 
He indicated that embezzlers are "opportunist's type", who quickly detects the lack of weakness in internal control and seizes the opportunity to use the deficiency to his benefit. To deter embezzlement, he recommended: (a) institute strong internal control policies, which reduce the opportunity of crime, and (b) conduct an aggressive and thorough background check prior to employment.

Bologna and Lindquist (1996) in their study cited the 'environmental' factors that enhance the probability of embezzlement of funds. However, Ziegenfuss (1996) performed a study to determine the amount and type of fraud occurring in 'state and local' governments. His study revealed that the most frequently occurring types of fraud are misappropriation of assets, theft, false representation; and false invoice. On the other hand, Haugen and Selin (1999) in their study discussed the value of 'internal' controls, which depends largely on management's integrity. Adding to the situation of poor internal controls, the readily available computer technology also assisted in the crime, and the opportunity to commit fraud becomes a reality. Sharma and Brahma (2000) have emphasized on 'bankers' responsibility on frauds; bank frauds could crop-up in all spheres of bank's dealing. Major cause for perpetration of fraud is laxity in observance in laid-down system and procedures by supervising staff. Harris and William (2004), however, examined the reasons for 'Ioan' frauds in banks and emphasized on due diligence program. They indicated that lack of an effective internal audit staff at the company, frequent turnover of management or directors, appointment of unqualified persons in key audit or finance posts, customer's reluctance to provide requested information or financial statements and fictitious or conflicting data provided by the customers are the main reasons for loan frauds.

Beirstaker, Brody, Pacini (2005) in their study proposed numerous fraud protection and detection techniques. Rezaee (2005), however, finds five interactive factors that explain several high-profile 'financial statement' frauds. These factors are: cooks, recipes, incentives, monitoring and end results (CRIME). Moreover, Willison (2006) examined the causes that led to the breakdown of 'Barring' Bank. The collapse resulted due to the failures in management, financial and operational controls of Baring Banks. Choo and Tan (2007) explained corporate fraud by relating the 'fraud-triangle' to the "broken trust theory" and to an "American Dream" theory, which originates from the sociological literature, while Schrand and Zechman (2007) relate executive over-confidence to the commitment of fraud. In fact, research results by Crutchley et al., (2007) have shown that "corporate environment most likely to lead to an accounting scandal manifests significant growth and accounting practices that are already pushing the envelope of 'earnings smoothing'. Firms operating in this environment seem more likely to tip over the edge into fraud if there are fewer outsiders on the audit committee and outside directors appear overcommitted." Moreover, Bhasin (2008) examined the reasons for 'check' frauds, the magnitude of frauds in Indian banks, and the manner, in which the expertise of internal auditors can be integrated, in order to detect and prevent frauds in banks. In addition to considering the common types of fraud signals, auditors can take several 'proactive' steps to combat frauds. In another study, Bhasin (2013) made an in-depth analysis of corporate accounting fraud at Satyam Computer Services Limited.

Chen (2010) in his study examined the proposition that "a major cause of the leading financial accounting scandals that received much publicity around the world was 'unethical' leadership in the companies and compares the role of unethical leaders in a variety of scenarios. Through the use of computer simulation models, it shows how a combination of CEO's narcissism, financial incentive, shareholders' expectations and subordinate silence as well as CEO's dishonesty can do much to explain some of the findings highlighted in recent high-profile financial accounting scandals." According to a research study performed by Cecchini et al., (2010), the authors provided a methodology for detecting 'management' fraud using basic financial data based on 'support vector machines'. A large empirical data set was collected, which included quantitative financial attributes for fraudulent and non-fraudulent public companies. They concluded that "Support vector machines using the financial kernel correctly labeled $80 \%$ of the fraudulent cases and $90.6 \%$ of the non-fraudulent cases on a holdout set. The results also show that the methodology has predictive value because, using only historical data, it was able to distinguish fraudulent from non-fraudulent companies in subsequent years."

An examination of prior literature reveals that the likelihood of committing fraud has typically been investigated using financial and/or governance variables. A large majority of these studies were 
performed in developed, Western countries. However, the manager's behavior in fraud commitment has been relatively unexplored so far. Unfortunately, no study has been conducted to examine behavioral aspects of manager's in the perpetuation of corporate frauds in the context of a developing economy, like India. Hence, the present study seeks to fill this gap and contributes to the literature.

\subsection{RESEARCH METHODOLOGY}

Financial reporting practice can be developed by reference to a particular setting in which it is embedded. Therefore, 'qualitative' research could be seen useful to explore and describe fraudulent financial reporting practice. Here, two issues are crucial. First, to understand why and how a 'specific' company is committed to fraudulent financial reporting practice an appropriate "interpretive" research approach is needed. Second, case study conducted as part of this study, looked specifically at the largest fraud case in India, involving Satyam Computer Services (Satyam). Labelled as "India's Enron" by the Indian media, the issue involved fraud and financial statement manipulation over a 10-year period, predominantly by the chairman, Ramalinga Raju (henceforth, Mr. Raju). It is India's fourth largest software services exporter having operations in 66 countries. The Satyam accounting fraud has, for the first time, comprehensively exposed the failure of the regulatory oversight mechanism in India. No doubt, to design better accounting systems, we need to understand how accounting systems operate in their social, political and economic contexts.

Recently, the accounting fraud of Satyam rocked the world; some even named it as Indian Enron. Satyam fraud is India's biggest corporate scandal since the early 1990 s and its first high-profile casualty since the start of the global financial crisis. The main objectives of this study are to: (1) identify the prominent American and foreign companies involved in fraudulent financial reporting practices and the nature of accounting irregularities they committed; (2) highlight the Satyam Computers Limited's accounting scandal by portraying the sequence of events, the aftermath of events, the key parties involved, and major follow-up actions undertaken in India; and (3) what lesions can be learned from Satyam scam?

To complement prior literature, we examined "documented behaviors in cases of corporate scandals, using the evidence taken from press articles (such as managers' quotes and journalists' analyses)." In this context, research-based evidence by Miller (2006) has shown that "press fulfill the role of a monitor or watchdog for accounting frauds by rebroadcasting information from other information intermediaries (analysts, auditors, and lawsuits) and by undertaking original investigation and analysis." In addition, we prepared the "Corporate Scandal Fact Sheet," which includes a list of 'short' vignettes on companies, and the names of the main characters involved in the corporate fraud scandals. To attain the above stated research objectives we applied a "content" analysis to the "press" articles.

In terms of information collection 'methodology', we searched for evidence from the U.S. press coverage contained in the "Factiva" database (also called Dow Jones Factiva). It is a non-academic database of international news containing 20,000 worldwide full-text publications including The Financial Times, The Wall Street Journal, as well as the continuous information from Reuters, Dow Jones, and the Associated Press. We also used SEC documents, to understand the technical and accounting aspects of the corporate fraud. For some companies, we also used the restatement reports. Thus, present study is primarily based on "secondary" sources of data, (EBSCO host database), gathered from the related literature published in the journals, newspaper, books, statements, reports. However, as stated earlier, the nature of study is "primarily qualitative, descriptive and analytical." However, no quantitative and statistical tools have been used for analysis of this case study.

\subsection{SATYAM COMPUTER SERVICES LIMITED: A CASE STUDY}

Satyam Systems, a global IT company based in India, has just been added to a notorious list of companies involved in fraudulent financial activities, one that includes such names as Enron, WorldCom, Societe General, Parmalat, Ahold, Allied Irish, Bearings and Kidder Peabody. Satyam's CEO, Ramalingam Raju, took responsibility for broad accounting improprieties that overstated the company's revenues and profits and reported a cash holding of approximately $\$ 1.04$ billion that simply did not exist. This leads one 
to ask a simple question: How does this keep happening? In his letter to his board, Satyam's Raju shows the markers of this pathology. He states that, "What started as a marginal gap between actual operating profits and ones reflected in the books of accounts continued to grow over the years. It has attained unmanageable proportions. ..." Later, he describes the process as "like riding a tiger, not knowing how to get off without being eaten."

To be able to compare what happened at Enron and Satyam, one needs to look into the basic functioning of both companies. The outcome at Satyam is, undoubtedly, better than Enron. It is quite obvious that the crucial difference was the presence of an agency - in Satyam, the government of India - to spearhead a damage control exercise and keep the company afloat. After all Enron, like Satyam, had its business and assets-namely, power plants and the marketing, commercial, and administrative infrastructure intact. Power, which was Enron's product and an essential utility, had an assured market. Despite these positives, Enron was simply allowed to collapse, causing pain all around. Comparing the results with Enron, the merits of the method tried in Satyam are quite clear. But the position is reversed when we look at how the wrongdoers in the two companies have been treated in the respective countries - India and the US (Vasudev, 2010). In this, the much-bemoaned inefficacy of the Indian legal system and the comparative efficiency of the American system are evident. The events also provide a measure of the ethical values, and that delicate thing called sense of honour, prevailing in the two societies. The pertinent question here is how were these companies able to misrepresent their assets to such a proportion without the knowledge of anyone within their organizations? Was it loyalty or fear or both that kept employees in these organizations from blowing the whistle on the wrongdoers? While the result of both frauds was an initial rise in stock price and although the scam in Satyam Computers Services Limited is being called "The Indian Enron," there are some differences (like corporate culture, route followed by management to falsify the information etc.) between these two episodes (Khedekar, 2010).

Even as Raju is widely blamed for unleashing "India's Enron," Chaudhuri points to a major difference between Enron and Satyam. "At Enron, the CEO stonewalled, while whistle-blowers came out with the truth," he says. "At Satyam, there were no whistle-blowers. The CEO blew the whistle on himself." In that sense, Raju did—ultimately — tell the truth and perhaps live up to the "Satyam" name. Unfortunately for him, the company, and India's IT industry, by then it was much too late. Useem draws a parallel between what occurred at Satyam with the scandals at WorldCom and Tyco, rather than at Enron. "At WorldCom, the CFO and the CEO were knowingly misstating the accounting and financials of the firm; at Tyco, the CEO and the CFO were knowingly taking money from the company for personal purposes," he says. "Satyam's disaster has a parallel to these acts of malfeasance."

Satyam scam has been the greatest scam in the history of the corporate world of the India. The case of Satyam accounting fraud has been dubbed by the media as "India's Enron". In order to evaluate and understand the severity of Satyam fraud, it is important to understand the factors that contributed to the 'unethical' decisions made by the company's executives. Therefore, it is necessary to examine in detail the rise of Satyam as a competitor within the global IT services market-place. In addition, it is also helpful to evaluate the driving-forces behind Satyam's decisions under the leadership of Ramalinga Raju (Chairman). Finally, attempt may be made to draw some broad conclusions and to learn some 'lessons' from Satyam fraud.

Ironically, Satyam means "truth" in the ancient Indian language "Sanskrit" (Basilico et al., 2012). Satyam won the "Golden Peacock Award" for the best governed company in 2007 and in 2009. From being India's IT "crown jewel" and the country's "fourth largest" company with high-profile customers, the outsourcing firm Satyam Computers has become embroiled in the nation's biggest corporate scam in living memory (Ahmad, et al., 2010). Mr. Ramalinga Raju (Chairman and Founder of Satyam; henceforth called 'Raju'), who has been arrested and has confessed to a \$1.47 billion (or Rs. 7,800 crore) fraud, admitted that he had made up profits for years. According to reports, Raju and his brother, B. Rama Raju, who was the Managing Director, "hid the deception from the company's board, senior managers, and auditors." The case of Satyam's accounting fraud has been dubbed as "India's Enron". In order to evaluate and understand the severity of Satyam's fraud, it is important to understand factors that contributed to the 'unethical' decisions made by the company's executives. First, it is necessary to detail 
the rise of Satyam as a competitor within the global IT services market-place. Second, it is helpful to evaluate the driving-forces behind Satyam's decisions: Ramalinga Raju. Finally, attempt to learn some 'lessons' from Satyam fraud for the future.

\subsection{EMERGENCE OF SATYAM COMPUTER SERVICES}

Satyam Computer Services Limited was a 'rising-star' in the Indian 'outsourced' IT-services industry. The company was formed in 1987 in Hyderabad (India) by Mr. Ramalinga Raju. The firm began with 20 employees and grew rapidly as a 'global' business. It offered IT and business process outsourcing (BPO) services spanning various sectors. Satyam was the 4th fastest growing IT Company, which operated in 65 countries around the world. The company, at that point, claimed to employ 52,865 workers and serve 690 companies, including 185 Fortune 500 firms. Work in the U.S. accounted for $62 \%$ of Satyam's revenues, and the company. In fact, Satyam had become deeply embedded as a "back office" IT services provider at the World Bank, and in 2005, the company registered as a potential vendor with the United Nations. With $9 \%$ market share along with \$2.1 Billion in revenue, everything was going great. Satyam was the first Indian company to be registered with three International Exchanges (NYSE, DOW Jones and EURONEXT).

Satyam was as an example of "India's growing success." Satyam won numerous awards for innovation, governance, and corporate accountability. As Agrawal and Sharma (2009) states, "In 2007, Ernst \& Young awarded Mr. Raju with the 'Entrepreneur of the Year' award. On April 14, 2008, Satyam won awards from MZ Consult's for being a 'leader in India in CG and accountability'. In September 2008, the World Council for Corporate Governance awarded Satyam with the 'Global Peacock Award' for global excellence in corporate accountability." Unfortunately, less than five months after winning the Global Peacock Award, Satyam became the centre-piece of a 'massive' accounting fraud.

By 2003, Satyam's IT services businesses included 13,120 technical associates servicing over 300 customers worldwide. At that time, the world-wide IT services market was estimated at nearly $\$ 400$ billion, with an estimated annual compound growth rate of $6.4 \%$. "The markets major drivers at that point in time were the increased importance of IT services to businesses world-wide; the impact of the Internet on eBusiness; the emergence of a high-quality IT services industry in India and their methodologies; and, the growing need of IT services providers who could provide a range of services." To effectively compete, both against domestic and global competitors, the company embarked on a variety of multi-pronged business growth strategies. In financial terms, Satyam displayed, in its reported statements, spectacular results in all key operating parameters (see Table-1).

\begin{tabular}{lrrrrrr}
\hline \multicolumn{3}{c}{ Table-1: Operating Performance of Satyam } & \multicolumn{2}{c}{ (Rs. in millions) } \\
\hline Particulars & $2003-04$ & $2004-05$ & $2005-06$ & $2006-07$ & $2007-08$ & $\begin{array}{r}\text { Average Growth } \\
\text { Rate (\%) }\end{array}$ \\
\hline Net Sales & & & & & & 38 \\
Operating Profit & $25,415.4$ & $34,642.2$ & $46,343.1$ & $62,284.7$ & $81,372.8$ & 28 \\
Net Profit & 7,743 & 9,717 & $15,714.2$ & $17,107.3$ & $20,857.4$ & 33 \\
Operating & $5,557.9$ & $7,502.6$ & $12,397.5$ & $14,232.3$ & $17,157.4$ & 35 \\
Flow & $4,165.5$ & $6,386.6$ & $7,868.1$ & $10,390.6$ & $13,708.7$ & 30 \\
ROCE (\%) & & & & & & \\
ROE (\%) & 27.95 & 29.85 & 31.34 & 31.18 & 29.57 & 26 \\
\hline
\end{tabular}

(Source: www.geogit.com)

From 2003-2008, in nearly all financial metrics of interest to investors, the company grew measurably. Satyam generated Rs. 25,415.4 million in total sales in 2003-04. By March 2008, the company sales revenue had grown by over three times. The company demonstrated "an annual compound growth rate of $38 \%$ over that period." Operating profits, net profit and operating cash flows averaged 28,33 and $35 \%$, respectively. Earnings per share similarly grew, from $\$ 0.12$ to $\$ 0.62$, at a compound annual growth rate of $40 \%$. Over the same period (2003-2009), the company was trading at an average trailing EBITDA 
multiple of 15.36. Finally, beginning in January 2003, at a share price of 138.08 INR, Satyam's stock would peak at 526.25 INR-a 300\% improvement in share price after nearly five years (www.capitaliq.com). Satyam clearly generated significant corporate growth and shareholder value. The company was a leading star-and a recognizable name-in a global IT marketplace. The external environment in which Satyam operated was indeed beneficial to the company's growth. But, the numbers did not represent the full picture. The case of Satyam accounting fraud has been dubbed as "India's Enron". Exhibit-1 lists some of the critical events for Satyam between 1987 and 2009. The case of Satyam accounting fraud has been dubbed as "India's Enron".

\section{Exhibit-1: Satyam Timeline}

June 24, 1987: Satyam Computers is launched in Hyderabad

1991: Debuts in Bombay Stock Exchange with an IPO over-subscribed 17 times.

2001: Gets listed on NYSE: Revenue crosses \$1 billion.

2008: Revenue crosses \$2 billion.

December 16, 2008: Satyam Computers announces buying of a 100 per cent stake in two companies owned by the Chairman Ramalinga Raju's sons-Maytas Properties and Maytas Infra. The proposed $\$ 1.6$ billion deal is aborted seven-hours later due to a revolt by investors, who oppose the takeover. But Satyam shares plunge 55\% in trading on the New York Stock Exchange.

December 23: The World Bank bars Satyam from doing business with the bank's direct contracts for a period of 8 years in one of the most severe penalties by a client against an Indian outsourcing company. In a statement, the bank says: "Satyam was declared ineligible for contracts for providing improper benefits to Bank staff and for failing to maintain documentation to support fees charged for its subcontractors." On the day the stock drops a further $13.6 \%$, it is lowest in more than four-and-a-half years.

December 25: Satyam demands an apology and a full explanation from the World Bank for the statements, which damaged investor confidence, according to the outsourcer. Interestingly, Satyam does not question the company being barred from contracts, or ask for the revocation of the bar, but instead objects to statements made by bank representatives. It also does not address the charges under which the World Bank said it was making Satyam ineligible for future contracts. December 26: Mangalam Srinivasan, an independent director at Satyam, resigns following the World Bank's critical statements.

December 28: Three more directors quit. Satyam postpones a board meeting, where it is expected to announce a management shakeup, from December 29 to January 10. The move aims to give the group more time to mull options beyond just a possible share buyback. Satyam also appoints Merrill Lynch to review 'strategic options to enhance shareholder value.'

January 2, 2009: Promoters' stake falls from $8.64 \%$ to $5.13 \%$ as institutions with whom the stake was pledged, dump the shares.

January 6, 2009: Promoters' stake falls to 3.6\%.

January 7, 2009: Ramalinga Raju resigns, admitting that the company inflated its financial results. He says the company's cash and bank shown in balance sheet have been inflated and fudged to the tune of INR 50,400 million. Other Indian outsourcers rush to assure credibility to clients and investors. The Indian IT industry body, National Association of Software and Service Companies, jumps to defend the reputation of the Indian IT industry as a whole.

January 8: Satyam attempts to placate customers and investors that it can keep the company afloat, after its former CEO admitted to India's biggest-ever financial scam. But law firms Izard Nobel and Vianale \& Vianale file "class-action suits on behalf of US shareholders," in the first legal actions taken against the management of Satyam in the wake of the fraud.

January 11: The Indian government steps into the Satyam outsourcing scandal and installs three people to a new board in a bid to salvage the firm. The board is comprised of Deepak S Parekh, the Executive Chairman of home-loan lender, Housing Development Finance Corporation (HDFC), C. Achuthan, Director at the country's National Stock Exchange, and former member of the Securities and Exchange Board of India, and Kiran Karnik, Former President of NASSCOM. 
January 12: The new board at Satyam holds a press conference, where it discloses that it is looking at ways to raise funds for the company and keep it afloat during the crisis. One such method to raise cash could be to ask many of its Triple A-rated clients to make advance payments for services. January 7, 2009: Ramalinga Raju dropped a letter-bomb on unsuspecting investors, employees and the government confessing to a Rs.7,136 crore fraud committed by him and his close circle of relatives and employees at the company. Ramalinga Raju resigns.

February 2009: $\mathrm{CBI}$ takes over investigation, goes on to file three charge sheets. Mar 6, 2009: Gets SEBI nod for bidding process to select investor.

April 22, 2009: Tech Mahindra makes open offer to Satyam shareholders at Rs. 58/share, offer to close June 9.

June 22, 2009: Mahindra unveils new brand identity for Satyam, Mahindra Satyam.

2010: Raju says charges levelled by CBI are false.

November 2, 2011: Supreme Court grants bail to Raju since CBI failed to file charge sheet on time.

October 28, 2013: Enforcement Directorate files a criminal complaint against 47 persons and 166 corporate entities headed by Ramalinga Raju.

July 2014: India's market regulator SEBI bars Raju from the capital markets for 14 years, and also seeks Rs1,849 crore as fine.

December 8, 2014: Ramalinga Raju and three others given six months jail term by SFIO.

December 23, 2014: Judge postpones verdict citing voluminous documents.

March 9, 2015: Special court defers verdict till April 9.

April 9, 2015: The special CBI court holds Raju and nine other officials guilty of cheating. Among those held guilty are two former partners at PWC. "We are disappointed with this verdict given by the court of the Additional Chief Metropolitan Magistrate at Hyderabad," accounting firm PwC said in a statement.

Raju, who also has to pay a fine of about $\$ 800,000$ (Rs5 crore), has served 32 months in prison so far.

(Source: Compiled by the author from various media reports)

\subsection{MR. RAMALINGA RAJU AND THE SATYAM SCANDAL}

On January 7, 2009, Mr. Raju disclosed in a letter, as shown in Exhibit-2, to Satyam Computers Limited Board of Directors that "he had been manipulating the company's accounting numbers for years." Mr. Raju claimed that he overstated assets on Satyam's balance sheet by $\$ 1.47$ billion. Nearly \$1.04 billion in bank loans and cash that the company claimed to own was non-existent. Satyam also underreported liabilities on its balance sheet. Satyam overstated income nearly every quarter over the course of several years in order to meet analyst expectations. For example, the results announced on October 17, 2009 overstated quarterly revenues by $75 \%$ and profits by $97 \%$. Mr. Raju and the company's global head of internal audit used a number of different techniques to perpetrate the fraud. As Ramachandran (2009) pointed out, "Using his personal computer, Mr. Raju created numerous bank statements to advance the fraud. Mr. Raju falsified the bank accounts to inflate the balance sheet with balances that did not exist. He inflated the income statement by claiming interest income from the fake bank accounts. Mr. Raju also revealed that he created 6,000 fake salary accounts over the past few years and appropriated the money after the company deposited it. The company's global head of internal audit created fake customer identities and generated fake invoices against their names to inflate revenue. The global head of internal audit also forged board resolutions and illegally obtained loans for the company." It also appeared that the cash that the company raised through American Depository Receipts in the United States never made it to the balance sheets.

\subsection{ANATOMY OF A FRAUD AT SATYAM}

It all started with Raju's love for land and that unquenchable thirst to own more and more of it. Ambition and risk ran in cahoots with his goals, mated with Maytas (nothing but Satyam when read from right to left), was an infrastructure company owned by Raju's sons, was a perfect recipe for disaster. So perfect was the scam that no auditor or analyst could even figure it out till Raju admitted to the massive 
irregularities in his self-confession. The trigger was obviously the failed attempt to merge Maytas with Satyam. The outrage over Raju's admission of systematic accounting fraud has broadened to wider concern about the potential damage to India's appeal for foreign investors and the IT services industry in particular. The Satyam scam took nearly two years and over 100 experts to assess the total damage of the scam perpetrated by Raju. The final figure was a shade under Rs. 8,000 crore. Satyam had tried to buy two infrastructure company run by his sons, including Maytas, in December 2008. The effort failed and in January 2009 Raju confessed to irregularity on his own, and was arrested two days later.

1. Maintaining Records: Mr. Raju maintained thorough details of the Satyam's accounts and minutes of meetings, since 2002. He stored records of accounts for the latest year (2008-09) in a computer server called "My Home Hub." Details of accounts from 2002 till January 7, 2009 - the day Mr. Raju came out with his dramatic (5-page confession) were stored in two separate Internet Protocol (IP) addresses.

2. Fake Invoices and Bills: Fake invoices and bills were created using the software applications, such as "Ontime" that was used for calculating hours put in by an employee. A secret program was allegedly planted in the source code of the official invoice management system creating a user ID "Super User" with the power to hide, or show the invoices in the system. Raju admitted to faking revenues, clients and even profits. The CID told the court that "Raju even falsified number of employees in the company by 13,000 and pocketed the money spent as salaries for these non-existent employees. He also faked 7561 invoices which raked up fake revenues to the tune of Rs. 5,117 crore, and raked up fake cash worth Rs. 3,983 crore. He tampered with the invoice management software to give birth to this massive scam which is worth Rs. 7,900 crore in its totality.

3. Web of Companies: A web of 356 investment companies was used to allegedly divert funds from Satyam Computers Limited. All these companies had several transactions in the form of inter-corporate investments, advances and loans within and among them. One such company, with a paid-up capital of Rs. 5 lakh, had made an investment of Rs. 90.25 crore, and received unsecured loans of Rs. 600 crore.

4. Why did he need the Money?: The cash so raised was used to purchase several thousands of acres of land, across Andhra Pradesh, to ride a booming realty market. It presented a growing problem as facts had to be doctored to keep showing healthy profits for Satyam that was growing in size and scale. Every attempt made to eliminate the gap failed. As Raju put it, "it was like riding a tiger, not knowing how to get off without being eaten." Cashing out by selling Maytas Infrastructure and Maytas Properties to Satyam for an estimated Rs. 7,800 crore was the last straw.

5. The Modus Operandi of Accounting Fraud: As financial frauds go, the one perpetrated by Raju \& Company was quite uncomplicated. Satyam's top management simply cooked the company's books by overstating its revenues, profit margins, and profits for every single quarter over a period of 5-years, from 2003 to 2008. Not for them complex methods like derivatives accounting or off-balance sheet transactions that were used by Enron's executives (Krishnan, 2014).

Keen to project a perpetually rosy picture of the company to investors, employees and analysts, the Rajus manipulated Satyam's books so that it appeared to be a far bigger enterprise than it actually was. To achieve this, they sewed up deals with fictitious clients, and introduced over 7,000 fake invoices into the company's computer systems to record sales that simply did not exist. For good measure, profits too were padded up to show healthy margins. Over the years, these ghostly clients understandably never paid their bills, leading to a big hole in Satyam's balance sheet. The hole was plugged by inflating the debtors (dues from clients) in the balance sheet and forging bank statements to show a mountain of cash and bank balances. After several years of such manipulation, Satyam was reporting sales of over Rs. 5,200 crore in 2008-09, when it was in reality making about Rs. 4,100 crore. Its operating profit margins were shown at $24 \%$ when they were actually at $3 \%$ and its handsome profits on paper covered up for reallife losses. It was when the company ran out of cash (of the real variety) to pay salaries that Ramalinga Raju decided that he could not ride the tiger any longer and made his confession. 
6. Riding a Tiger: Raju was compelled to admit to the fraud following an aborted attempt to have Satyam invest \$1.6 billion in Maytas Properties and Maytas Infrastructure ("Maytas" is Satyam spelled backwards) - two firms promoted and controlled by his family members. On December 16, Satyam's board cleared the investment, sparking a negative reaction by investors, who pummeled its stock on the New York Stock Exchange and Nasdaq. The board hurriedly reconvened the same day and called off the proposed investment. The matter did not die there, as Raju may have hoped. In the next 48 hours, resignations streamed in from Satyam's non-executive director, Krishna Palepu, and three independent directors. The attempt finally failed, and Raju made the stunning confessions three weeks later.

7. Truth in Numbers: Notwithstanding Raju's confession, the Satyam episode has brought into sharp relief the role and efficacy of independent directors. SEBI requires Indian publicly held companies to ensure that independent directors make up at least half their board strength. The knowledge available to independent directors and even audit committee members is inherently limited to prevent willful withholding of crucial information. The reality is, at the end of the day, even as an audit committee member or as an independent director, I would have to rely on what the management was presenting to me, drawing upon his experience as an independent director and audit committee member. "It is the auditors' job to see if the numbers presented are accurate." That is what the directors should have been asking." Instead, he adds, like the dog that didn't bark in the Sherlock Holmes story, the matter was allowed to slide. Even if outside directors were unaware of the true state of Satyam's finances, some red flags should have been obvious.

8. Punishment by the Court: Accused in the case, including Raju, were charged with cheating, criminal conspiracy, forgery, breach of trust, inflating invoices, profits, faking accounts and violating number of income tax laws. The CBI has filed three charge-sheets in the case which were later clubbed into one massive charge-sheet running over 55,000 pages. Over 3000 documents and 250 witnesses were parsed over the past 6 years. As the judge reads his verdict on Monday, it remains to be seen whether the scam that shook India and the private sector for its sheer magnitude and brought to dust the edifice of India Inc. will finally get its much deserved closure or not.

Satyam's finances were a black-box with an access card so rare that only Raju and his confidants knew what exactly was going on in the company. Ganesh Natarajan of Zensar Technologies famously said, "If anybody in the industry is capable of pulling off a scam like this, it would be Ramalinga Raju... the capability, the thinking through, the planning of such a large operation.... .only he had the ability to pull it off." A special CBI court on April 9, 2015 finally, sentenced B. Ramalinga Raju, his two brothers and seven others to seven years in prison in the Satyam fraud case. The court also imposed a fine of Rs. 5 crore on Ramalinga Raju, the Satyam Computer Services Ltd's founder and former chairman, and his brother B Rama Raju, and Rs. 20-25 lakh each on the remaining accused. The 10 people found guilty in the case are: B. Ramalinga Raju; his brother and Satyam's former managing director B. Rama Raju; former chief financial officer Vadlamani Srinivas; former PwC auditors Subramani Gopalakrishnan and T Srinivas; Raju's another brother B Suryanarayana Raju; former employees G. Ramakrishna, D. Venkatpathi Raju and Ch Srisailam; and Satyam's former internal chief auditor V.S. Prabhakar Gupta.

\section{Exhibit-2: Satyam's Founder, Chairman and CEO, Mr. Raju's Letter to his Board of Directors}

To The Board of Directors, January 7, 2009

Satyam Computer Services Ltd.

From: B. Ramalinga Raju

Chairman, Satyam Computer Services Ltd.

Dear Board Members,

It is with deep regret, and tremendous burden that I am carrying on my conscience, that I would like to bring the following facts to your notice:

1. The Balance Sheet carries as of September 30, 2008:

(a) Inflated (non-existent) cash and bank balances of Rs.5,040 crore (as against Rs. 5,361 crore reflected in the books); (b) An accrued interest of Rs. 376 crore which is non-existent; (c) An 
understated liability of Rs. 1,230 crore on account of funds arranged by me; and (d) An over stated debtors position of Rs. 490 crore (as against Rs. 2,651 reflected in the books).

2. For the September quarter (Q2), we reported a revenue of Rs.2,700 crore and an operating margin of Rs. 649 crore (24\% of revenues) as against the actual revenues of Rs. 2,112 crore and an actual operating margin of Rs. 61 Crore (3\% of revenues). This has resulted in artificial cash and bank balances going up by Rs. 588 crore in Q2 alone.

The gap in the Balance Sheet has arisen purely on account of inflated profits over a period of last several years (limited only to Satyam standalone, books of subsidiaries reflecting true performance). What started as a marginal gap between actual operating profit and the one reflected in the books of accounts continued to grow over the years. It has attained unmanageable proportions as the size of company operations grew significantly (annualized revenue run rate of Rs. 11,276 crore in the September quarter, 2008 and official reserves of Rs. 8,392 crore). The differential in the real profits and the one reflected in the books was further accentuated by the fact that the company had to carry additional resources and assets to justify higher level of operations - thereby significantly increasing the costs.

Every attempt made to eliminate the gap failed. As the promoters held a small percentage of equity, the concern was that poor performance would result in a take-over, thereby exposing the gap. It was like riding a tiger, not knowing how to get off without being eaten.

The aborted Maytas acquisition deal was the last attempt to fill the fictitious assets with real ones. Maytas' investors were convinced that this is a good divestment opportunity and a strategic fit. Once Satyam's problem was solved, it was hoped that Maytas' payments can be delayed. But that was not to be. What followed in the last several days is common knowledge.

I would like the Board to know:

1. That neither myself, nor the Managing Director (including our spouses) sold any shares in the last eight years-excepting for a small proportion declared and sold for philanthropic purposes.

2. That in the last two years a net amount of Rs. 1,230 crore was arranged to Satyam (not reflected in the books of Satyam) to keep the operations going by resorting to pledging all the promoter shares and raising funds from known sources by giving all kinds of assurances (Statement enclosed, only to the members of the board). Significant dividend payments, acquisitions, capital expenditure to provide for growth did not help matters. Every attempt was made to keep the wheel moving and to ensure prompt payment of salaries to the associates. The last straw was the selling of most of the pledged share by the lenders on account of margin triggers.

3. That neither me, nor the Managing Director took even one rupee/dollar from the company and have not benefitted in financial terms on account of the inflated results.

4. None of the board members, past or present, had any knowledge of the situation in which the company is placed. Even business leaders and senior executives in the company, such as, Ram Mynampati, Subu D, T.R. Anand, Keshab Panda, Virender Agarwal, A.S. Murthy, Hari T, SV Krishnan, Vijay Prasad, Manish Mehta, Murali V, Sriram Papani, Kiran Kavale, Joe Lagioia, Ravindra Penumetsa, Jayaraman and Prabhakar Gupta are unaware of the real situation as against the books of accounts. None of my or Managing Director's immediate or extended family members has any idea about these issues.

Having put these facts before you, I leave it to the wisdom of the board to take the matters forward. However, I am also taking the liberty to recommend the following steps:

1. A Task Force has been formed in the last few days to address the situation arising out of the failed Maytas acquisition attempt. This consists of some of the most accomplished leaders of Satyam: Subu D, T.R. Anand, Keshab Panda and Virender Agarwal, representing business functions, and A.S. Murthy, Hari T and Murali V representing support functions. I suggest that Ram Mynampati be made the Chairman of this Task Force to immediately address some of the operational matters on hand. Ram can also act as an interim CEO reporting to the board.

2. Merrill Lynch can be entrusted with the task of quickly exploring some Merger opportunities.

3. You may have a 'restatement of accounts' prepared by the auditors in light of the facts that I have placed before you. I have promoted and have been associated with Satyam for well over twenty years now. I have seen it grow from few people to 53,000 people, with 185 Fortune 500 companies as customers and operations in 66 countries. Satyam has established an excellent 
leadership and competency base at all levels. I sincerely apologize to all Satyamites and stakeholders, who have made Satyam a special organization, for the current situation. I am confident they will stand by the company in this hour of crisis. In light of the above, I fervently appeal to the board to hold together to take some important steps. Mr. T.R. Prasad is well placed to mobilize support from the government at this crucial time. With the hope that members of the Task Force and the financial advisor, Merrill Lynch (now Bank of America) will stand by the company at this crucial hour, I am marking copies of this statement to them as well.

Under the circumstances, I am tendering my resignation as the chairman of Satyam and shall continue in this position only till such time the current board is expanded. My continuance is just to ensure enhancement of the board over the next several days or as early as possible.

I am now prepared to subject myself to the laws of the land and face consequences thereof. Signature

\section{(B. Ramalinga Raju)}

(Source: Letter distributed by the Bombay Stock Exchange and Security and Exchange Board of India, available at www.sebi.gov.in )

Greed for money, power, competition, success and prestige compelled Mr. Raju to "ride the tiger," which led to violation of all duties imposed on them as fiduciaries-the duty of care, the duty of negligence, the duty of loyalty, the duty of disclosure towards the stakeholders. According to Damodaran (2012), "The Satyam scandal is a classic case of negligence of fiduciary duties, total collapse of ethical standards, and a lack of corporate social responsibility. It is human greed and desire that led to fraud. This type of behavior can be traced to greed overshadowing the responsibility to meet fiduciary duties; fierce competition and the need to impress stakeholders especially investors, analysts, shareholders, and the stock market; low ethical and moral standards by top management; and, greater emphasis on short-term performance." According to $\mathrm{CBI}$, the Indian crime investigation agency, the fraud activity dates back from April 1999, when the company embarked on a road to double-digit annual growth. As of December 2008, Satyam had a total market capitalization of $\$ 3.2$ billion dollars (Dixit, 2009).

Satyam planned to acquire a $51 \%$ stake in Maytas Infrastructure Limited, a leading infrastructure development, construction and project management company, for $\$ 300$ million. Here, the Rajus's had a $37 \%$ stake. The total turnover was $\$ 350$ million and a net profit of $\$ 20$ million. Raju's also had a $35 \%$ share in Maytas Properties, another real-estate investment firm. Satyam revenues exceeded \$1 billion in 2006. In April, 2008 Satyam became the first Indian company to publish IFRS audited financials. On December 16,2008 , the Satyam board, including its five independent directors had approved the founder's proposal to buy the stake in Maytas Infrastructure and all of Maytas Properties, which were owned by family members of Satyam's Chairman, Ramalinga Raju, as fully owned subsidiary for \$1.6 billion. Without shareholder approval, the directors went ahead with the management's decision. The decision of acquisition was, however, reversed twelve hours after investors sold Satyam's stock and threatened action against the management. This was followed by the law-suits filed in the U.S. contesting Maytas deal. The World Bank banned Satyam from conducting business for 8 years due to inappropriate payments to staff and inability to provide information sought on invoices (www.slideshare.net). Four independent directors quit the Satyam board and SEBI ordered promoters to disclose pledged shares to stock exchange.

According to Investors Protection and Redressal Forum, "Investment bank DSP Merrill Lynch, which was appointed by Satyam to look for a partner or buyer for the company, ultimately blew the whistle and terminated its engagement with the company soon after it found financial irregularities" (Blakely, 2009). In the context of whistle-blowing, Bowen et al., (2010) concludes that "Our results suggest whistleblowing is far from a trivial nuisance for targeted firms, and on average, appears to be a useful mechanism for uncovering agency issues." On 7 January 2009, Saytam's Chairman, Ramalinga Raju, resigned after notifying board members and the Securities and Exchange Board of India (SEBI) that Satyam's accounts had been falsified. Raju confessed that Satyam's balance sheet of September 30, 2008, contained the following irregularies: "He faked figures to the extent of Rs. 5,040 crore of nonexistent cash and bank balances as against Rs. 5,361 crore in the books, accrued interest of Rs. 376 crore 
(non-existent), understated liability of Rs. 1,230 crore on account of funds raised by Raju, and an overstated debtor's position of Rs. 490 crore. He accepted that Satyam had reported revenue of Rs. 2,700 crore and an operating margin of Rs. 649 crore, while the actual revenue was Rs. 2,112 crore and the margin was Rs. 61 crore." In other words, Raju: (a) inflated figures for cash and bank balances of US\$1.04 billion vs. US\$1.1 billion reflected in the books; (b) an accrued interest of US\$77.46 million which was non-existent; (c) an understated liability of US\$253.38 million on account of funds was arranged by himself; and (d) an overstated debtors' position of US\$100.94 million vs. US\$546.11 million in the books.

Raju claimed in the same letter that "neither he nor the managing director had benefited financially from the inflated revenues, and none of the board members had any knowledge of the situation in which the company was placed." The fraud took place to divert company funds into real-estate investment, keep high earnings per share, raise executive compensation, and make huge profits by selling stake at inflated price. In this context, Kripalani (2009) stated, "The gap in the balance sheet had arisen purely on account of inflated profits over a period that lasted several years starting in April 1999." "What accounted as a marginal gap between actual operating profit and the one reflected in the books of accounts continued to grow over the years. This gap reached unmanageable proportions as company operations grew significantly," Ragu explained in his letter to the board and shareholders. He went on to explain, "Every attempt to eliminate the gap failed, and the aborted Maytas acquisition deal was the last attempt to fill the fictitious assets with real ones. But the investors thought it was a brazen attempt to siphon cash out of Satyam, in which the Raju family held a small stake, into firms the family held tightly (D'Monte, 2008). Table-2 depicts some parts of the Satyam's fabricated 'Balance Sheet and Income Statement' and shows the 'difference' between 'actual' and 'reported' finances.

Table-2: Fabricated Balance Sheet and Income Statement of Satyam: As of September 30, 2008

\begin{tabular}{lrrr} 
& Actual & Reported & Difference \\
Cash and Bank Balances & 321 & 5,361 & $\mathbf{5 , 0 4 0}$ \\
Accrued Interest on bank FDs & $\mathrm{Nil}$ & 376.5 & $\mathbf{3 7 6}$ \\
Understated Liability & 1,230 & None & $\mathbf{1 , 2 3 0}$ \\
Overstated Debtors & 2,161 & 2,651 & $\mathbf{4 9 0}$ \\
Total & $\mathrm{Nil}$ & $\mathrm{Nil}$ & $\mathbf{7 , 1 3 6}$ \\
Revenues (Q2 FY 2009) & 2,112 & 2,700 & $\mathbf{5 8 8}$ \\
Operating Profits & 61 & 649 & $\mathbf{5 8 8}$ \\
\hline
\end{tabular}

Fortunately, the Satyam deal with Matyas was 'salvageable'. It could have been saved only if "the deal had been allowed to go through, as Satyam would have been able to use Maytas'assets to shore up its own books." Raju, who showed 'artificial' cash on his books, had planned to use this 'non-existent' cash to acquire the two Maytas companies (Ahmad, 2010). As part of their "tunneling" strategy, the Satyam promoters had substantially reduced their holdings in company from $25.6 \%$ in March 2001 to $8.74 \%$ in March 2008. Furthermore, as the promoters held a very small percentage of equity (mere $2.18 \%$ ) on December 2008, as shown in Table-3, the concern was that poor performance would result in a takeover bid, thereby exposing the gap. It was like "riding a tiger, not knowing how to get off without being eaten." The aborted Maytas acquisition deal was the final, desperate effort to cover up the accounting fraud by bringing some real assets into the business. When that failed, Raju confessed the fraud. Given the stake the Rajus held in Matyas, pursuing the deal would not have been terribly difficult from the perspective of the Raju family. As pointed out by Shirur (2011), "Unlike Enron, which sank due to agency problem, Satyam was brought to its knee due to tunneling. The company with a huge cash pile, with promoters still controlling it with a small per cent of shares (less than 3\%), and trying to absorb a realestate company in which they have a majority stake is a deadly combination pointing prima facie to tunneling." The reason why Ramalinga Raju claims that he did it was because every year he was fudging revenue figures and since expenditure figures could not be fudged so easily, the gap between 'actual' profit and 'book' profit got widened every year. In order to close this gap, he had to buy Maytas Infrastructure and Maytas Properties. In this way, 'fictitious' profits could be absorbed through a 'selfdealing' process. The auditors, bankers, and SEBI, the market watchdog, were all blamed for their role in the accounting fraud. 


\begin{tabular}{|c|c|c|c|c|c|c|c|c|c|}
\hline \multicolumn{10}{|c|}{ Table-3: Promoter's Shareholding pattern in Satyam } \\
\hline Particulars & $\begin{array}{r}\text { March } \\
2001\end{array}$ & $\begin{array}{r}\text { March } \\
2002\end{array}$ & $\begin{array}{r}\text { March } \\
2003\end{array}$ & $\begin{array}{r}\text { March } \\
2004\end{array}$ & $\begin{array}{r}\text { March } \\
2005\end{array}$ & $\begin{array}{r}\text { March } \\
2006\end{array}$ & $\begin{array}{r}\text { March } \\
2007\end{array}$ & $\begin{array}{r}\text { March } \\
2008\end{array}$ & $\begin{array}{r}\text { Dec. } \\
2008\end{array}$ \\
\hline $\begin{array}{l}\text { Promoter's } \\
\text { holding in } \\
\text { Percentage }\end{array}$ & 25.6 & 22.26 & 20.74 & 17.35 & 15.67 & 14.02 & 8.79 & 8.74 & 2.18 \\
\hline
\end{tabular}

Investigations into Satyam scam by the Crime Investigation Department (CID) of the State Police and Central agencies have established that the promoters indulged in nastiest kind of insider trading of the company's shares to raise money for building a large land bank. According to the SFIO findings, promoters of Satyam and their family members during April 2000 to January 7, 2009 sold almost 3.9 crore shares collecting in Rs. 3029.67 crore. During this course, the founder ex-chairman Ramalinga Raju sold 98 lakh shares collecting in Rs. 773.42 crores, whereas, his brother Rama Raju, sold 1.1 crore shares pocketing Rs. 894.32 crores. Table-4 provides details of sale of shares by the promoters and their family. Finding these top managers guilty of unfair manipulation of stock prices and insider trading, SEBI has asked them to deposit their 'unlawful gains' of Rs. 1850 crore, with 12 per cent interest, with the regulator within 45 days. They have also been barred from associating with the securities markets in any manner, for the next 14 years.

Table-4: Stake Sale by Promoters of Satyam

\begin{tabular}{lrr}
\hline Name of Promoter & No. of Shares & Money Earned Rs. in \\
& Sold & Crore \\
\hline B. Ramalinga Raju & $98,25,000$ & 773.42 \\
B. Rama Raju & $1,13,18,500$ & 894.32 \\
B. Suryanarayana Raju & $1,11,000$ & 12.81 \\
B. Nandini Raju & $40,47,000$ & 327.59 \\
B. Radha & $38,73,500$ & 313.55 \\
B. Jhansi Rani & $1,00,000$ & 11.25 \\
B. Pritam Teja & $9,42,250$ & 49.01 \\
B. Rama Raju (Jr.) & $9,34,250$ & 48.59 \\
Maytas Infra Ltd (Satyam Construction Ltd.) & 0 & 0.00 \\
B. Satyanarayana Raju & 0 & 0.00 \\
B. Appal Anarsamma & 0 & 0.00 \\
Elem Investments Pvt. Ltd. & $25,47,708$ & 181.29 \\
Fincity Investments Pvt. Ltd. & $25,30,400$ & 180.41 \\
Highgrace Investments Pvt. Ltd. & $25,30,332$ & 170.83 \\
Veeyes Investments Pvt. Ltd. & 57,500 & 71.79 \\
Other Individuals connected to investment co's & 68,000 & 515.58 \\
Off-market transfers by investment co's in the year & $1,90,000$ & 78.29 \\
2001 (value estimated) & & \\
Promoters Group Total & $3,90,75,440$ & $3,029.67$ \\
\hline
\end{tabular}

On 7 January 2009, the Indian stock market regulator, the Securities and Exchange Board of India (SEBI) commenced investigations under various SEBI regulations. The Ministry of Corporate Affairs of the Central Government separately initiated a fraud investigation through its Serious Fraud Investigation Office (SFIO). In addition, the Ministry of Corporate Affairs filed a petition before the Company Law Board (CLB) to prevent the existing directors from acting on the Board and to appoint new directors. On 9 January 2009, the CLB suspended the current directors of Satyam and allowed the Government to appoint up to 10 new nominee directors. Subsequently, the new, six-member Board has appointed a Chief Executive Officer and external advisors, including the accounting firms KPMG and Deloitte to restate the accounts of Satyam. 


\subsection{THE AUDITORS ROLE AND FACTORS CONTRIBUTING TO FRAUD}

Global auditing firm, PricewaterhouseCoopers (PwC), audited Satyam's books from June 2000 until the discovery of the fraud in 2009. Several commentators criticized PwC harshly for failing to detect the fraud (Winkler, 2010). Indeed, PwC signed Satyam's financial statements and was responsible for the numbers under the Indian law. One particularly troubling item concerned the \$1.04 billion that Satyam claimed to have on its balance sheet in "non-interest-bearing" deposits. According to accounting professionals, "any reasonable company would have either invested the money into an interest-bearing account, or returned the excess cash to the shareholders. The large amount of cash thus should have been a 'redflag' for the auditors that further verification and testing was necessary. As to the external auditors who are supposed to look out for investors, they seem to have been quite a trusting lot. While verifying bank balances, they relied wholly on the (forged) fixed deposit receipts and bank statements provided by the 'Chairman's office'. The forensic audit reveals differences running into hundreds of crores between the fake and real statements as captured by the computerised accounting systems. But for some strange reason, everyone, from the internal auditor to the statutory auditors, chose to place their faith in the 'Chairman's office' rather than the company's information systems. Furthermore, it appears that the auditors did not independently verify with the banks in which Satyam claimed to have deposits" (Kahn, 2009).

Additionally, the Satyam fraud went on for a number of years and involved both the manipulation of balance sheets and income statements. Whenever Satyam needed more income to meet analyst estimates, it simply created 'fictitious' sources and it did so numerous times, without the auditors ever discovering the fraud. Furthermore, PwC audited the company for nearly 9 years and did not uncover the fraud, whereas Merrill Lynch discovered the fraud as part of its due diligence in merely 10 days. Missing these "red-flags" implied either that the auditors were grossly inept or in collusion with the company in committing the fraud. PWC initially asserted that it performed all of the company's audits in accordance with applicable auditing standards. But can you bamboozle those watchdogs, the auditors? "Yes, you can," SEBI's investigations show. Both Satyam's internal as well as statutory auditors did not bring it to anyone's notice. As to the external auditors who are supposed to look out for investors, they seem to have been quite a trusting lot. While verifying bank balances, they relied wholly on the (forged) fixed deposit receipts and bank statements provided by the 'Chairman's office'. The forensic audit reveals differences running into hundreds of crores between the fake and real statements as captured by the computerised accounting systems (Bhasin, 2008). But for some strange reason, everyone, from the internal auditor to the statutory auditors, chose to place their faith in the 'Chairman's office' rather than the company's information systems.

A point has also been raised about the increase in audit fee. A reference to the figures of audit fee in comparison with total income over a period of time may be pertinent. Table- 5 shows that over a period of four years, 2004-05 to 2007-08, the audit fee increased by 5.7 times, whereas total income increased by 2.47 times during the same period. Nevertheless, it is difficult to draw any conclusion as to whether the increase in audit fee was justified or not. Suspiciously, Satyam also paid PwC twice what other firms would charge for the audit, which raises questions about whether PwC was complicit in the fraud.

\begin{tabular}{lccrr}
\hline \multicolumn{5}{c}{ Table-5: Satyam's Total Income and Audit Fees } \\
\hline Year & $2004-05$ & $2005-06$ & $2006-07$ & $2007-08$ \\
\hline Total Income (A) & 35,468 & $50,122.2$ & $64,100.8$ & $83,944.8$ \\
Audit Fees (B) & 6.537 & 11.5 & 36.7 & 37.3 \\
\% of B to A & 0.0184 & 0.0229 & 0.0573 & 0.0444 \\
\hline
\end{tabular}

Numerous factored contributed to the Satyam fraud. The independent board members of Satyam, the institutional investor community, the SEBI, retail investors, and the external auditor-none of them, including professional investors with detailed information and models available to them, detected the 
malfeasance. The following is a list of factors that contributed to the fraud: greed, ambitious corporate growth, deceptive reporting practices-lack of transparency, excessive interest in maintaining stock prices, executive incentives, stock market expectations, nature of accounting rules, ESOPs issued to those who prepared fake bills, high risk deals that went sour, audit failures (internal and external), aggressiveness of investment and commercial banks, rating agencies and investors, weak independent directors and audit committee, and whistle-blower policy not being effective.

\subsection{AFTERMATH OF SATYAM SCANDALS}

Immediately following the news of the fraud, Merrill Lynch terminated its engagement with Satyam, Credit Suisse suspended its coverage of Satyam, and PricewaterhouseCoopers (PwC) came under intense scrutiny and its license to operate was revoked. Coveted awards won by Satyam and its executive management were stripped from the company (Agarwal and Sharma, 2009). At its peak market capitalization, Satyam was valued at Rs. 36,600 crore in 2008. Just a year later, the scam-hit Satyam was snapped up by Tech Mahindra for a mere Rs. 58 per share-a market cap of a mere Rs. 5600 crore. The stock that hit its all-time high of Rs. 542 in 2008 crashed to an unimaginable Rs. 6.30 on the day Raju confessed on January 9, 2009.

Satyam's shares fell to 11.50 rupees on January 10, 2009, their lowest level since March 1998, compared to a high of 544 rupees in 2008. In the New York Stock Exchange, Satyam shares peaked in 2008 at US\$ 29.10; by March 2009 they were trading around US $\$ 1.80$. Thus, investors lost $\$ 2.82$ billion in Satyam (BBC News, 2009). Unfortunately, Satyam significantly inflated its earnings and assets for years and rolling down Indian stock markets and throwing the industry into turmoil (Timmons and Wassener, 2009). Criminal charges were brought against Mr. Raju, including: criminal conspiracy, breach of trust, and forgery. After the Satyam fiasco and the role played by PwC, investors became wary of those companies who are clients of PwC (Blakely), which resulted in fall in share prices of around 100 companies varying between 5-15\%. The news of the scandal (quickly compared with the collapse of Enron) sent jitters through the Indian stock market, and the benchmark Sensex index fell more than 5\%. Shares in Satyam fell more than 70\%. The graph "Fall from Grace," shown in Exhibit-3 depicts the Satyam's stock decline between December 2008 and January 2009.

Exhibit-3: Stock Charting of Satyam from December 2008 to January 2009

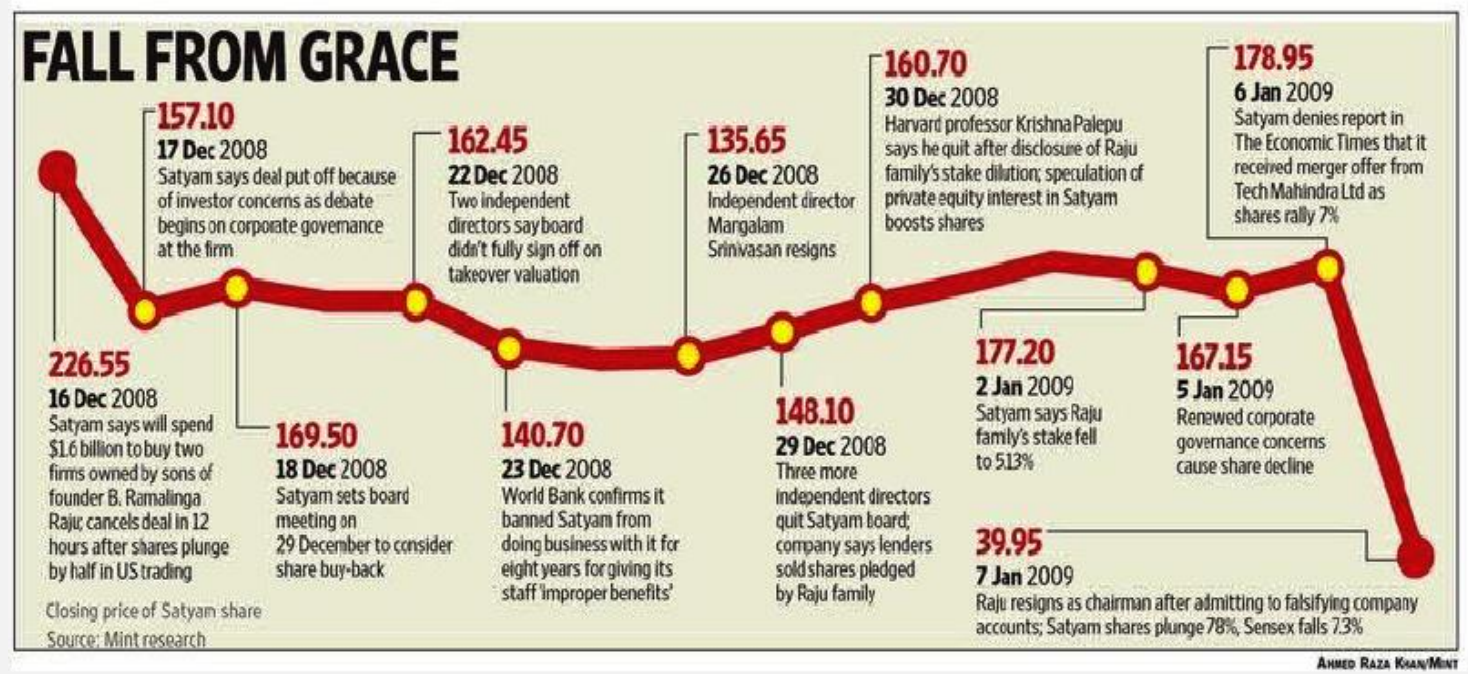

Immediately after Raju's revelation about the accounting fraud, 'new' board members were appointed and they started working towards a solution that would prevent the total collapse of the firm. Indian officials acted quickly to try to save Satyam from the same fate that met Enron and WorldCom, when they experienced large accounting scandals. The Indian government "immediately started an 
investigation, while at the same time limiting its direct participation, with Satyam because it did not want to appear like it was responsible for the fraud, or attempting to cover up the fraud." The government appointed a 'new' board of directors for Satyam to try to save the company. The Board's goal was "to sell the company within 100 days." To devise a plan of sale, the board met with bankers, accountants, lawyers, and government officials immediately. It worked diligently to bring stability and confidence back to the company to ensure the sale of the company within the 100-day time frame. To accomplish the sale, the board hired Goldman Sachs and Avendus Capital and charged them with selling the company in the shortest time possible.

By mid-March, several major players in the IT field had gained enough confidence in Satyam's operations to participate in an auction process for Satyam. The Securities and Exchange Board of India (SEBI) appointed a retired Supreme Court Justice, Justice Bharucha, to oversee the process and instill confidence in the transaction. Several companies bid on Satyam on April 13, 2009. The winning bidder, Tech Mahindra, bought Satyam for \$1.13 per share-less than a third of its stock market value before Mr. Raju revealed the fraud-and salvaged its operations (Dagar, 2009). Both Tech Mahindra and the SEBI are now fully aware of the full extent of the fraud and India will not pursue further investigations. The stock has again stabilized from its fall on November 26, 2009 and, as part of Tech Mahindra, Saytam is once again on its way toward a bright future.

\subsection{INVESTIGATION: CRIMINAL, CIVIL CHARGES AND VICTIMS}

The Satyam fraud has highlighted the multiplicity of regulators, courts and regulations involved in a serious offence by a listed company in India. The investigation that followed the revelation of the fraud has led to charges against several different groups of people involved with Satyam. Indian authorities arrested Mr. Raju, Mr. Raju's brother, B. Ramu Raju, its former managing director, Srinivas Vdlamani, the company's head of internal audit, and its CFO on criminal charges of fraud. Indian authorities also arrested and charged several of the company's auditors (PWC) with fraud. The Institute of Chartered Accountants of India (ICAI 2009) ruled that "the CFO and the auditor were guilty of professional misconduct." The CBI is also in the course of investigating the CEO's overseas assets. There were also several civil charges filed in the U.S. against Satyam by the holders of its ADRs. The investigation also implicated several Indian politicians. Both civil and criminal litigation cases continue in India and civil litigation continues in the United States. Some of the main victims, according to Manoharan (2011), were:

- Employees of Satyam spent anxious moments and sleep-less nights as they faced non-payment of salaries, project cancellations, layoffs and equally-bleak prospects of outside employment opportunities. They were stranded in many ways: morally, financially, legally, and socially.

- Clients of Satyam expressed loss of trust and reviewed their contracts, preferring to go with other competitors. Several global clients, like Cisco, Telstra and World Bank cancelled their contracts with the Satyam. "Customers were shocked and worried about the project continuity, confidentiality and cost overrun."

- Shareholders lost their valuable investments and there was doubt about revival of India, as a preferred investment destination. The VC and MD of Mahindra, in a statement, said that the development had "resulted in incalculable and unjustifiable damage to Brand India and Brand-IT, in particular."

- Bankers were concerned about recovery of financial and non-financial exposure and recalled facilities.

- Indian Government was worried about its image of the nation and IT-sector affecting faith to invest, or to do business in the county.

In the aftermath of Satyam, India's markets recovered and Satyam now lives on. India's stock market is currently trading near record highs, as it appears that a global economic recovery is taking place. Civil litigation and criminal charges continue against Satyam. Tech Mahindra purchased 51\% of Satyam on April 16,2009 , successfully saving the firm from a complete collapse. As Winkler states (2010), "With the right changes, India can minimize the rate and size of accounting fraud in the Indian capital markets." 


\subsection{REGULATORY CG REFORMS IN INDIA AND LESSONS LEARNED AT SATYAM}

No one can stop a cheat from committing a crime. But the fraud at Satyam went undetected for five years, suggesting that governance failures bear some blame. The \$1 billion accounting scandal at India's Satyam Computer Services has raised several key governance questions about the company's board and its auditors. One of the most perplexing is: Where does the buck stop. That is, why did not oversight mechanisms uncover the fraud sooner?

India immediately portrayed the Satyam scandal as an aberration to try to salvage the remaining confidence in its capital markets. Several commentators, however, claimed that the scandal was not an aberration, but a sign of governance issues in India. After the Satyam scandal, investors and regulators called for strengthening the regulatory environment in the securities markets. In response to the scandal, the SEBI revised CG requirements as well as financial reporting requirements for publicly traded corporations listed in the country. The SEBI also strengthened its commitment to the adoption of International Financial Accounting Reporting Standards (IFRS). In addition, the Ministry of Corporate Affairs (MCA) is devising a new Corporate Code and is considering changing the securities laws to make it easier for shareholders to bring class action lawsuits. Some of the recent CG reforms undertaken in India are:

(a) Independent Directors: The Satyam scandal reinforced the Indian regulators commitment to continue the process of CG reform. Even before the Satyam scandal broke, India was in the process of updating its 1956 Companies Act, which sets out key Indian CG rules. The SEBI is considering several proposals ranging from mandating increased due diligence on transactions to increasing personal liability of board members. If reform continues on its current course, reform within the 1956 Companies Act will make it easier for shareholders to sue officers and directors of corporations. The SEBI is also considering making publicly listed companies carry director and officer liability insurance to protect shareholders from damages. Additionally, the SEBI proposed creating a law that provides whistle-blowers with protection for reporting fraudulent activity. Finally, the SEBI revised takeover regulations to increase disclosure in takeovers.

(b) Disclosure of Pledged Securities: After Satyam, the SEBI increased disclosure obligations of promoters and controlling shareholders. Before the Satyam scandal, promoters and controlling shareholders were not required to disclose to investors if they had pledged their stock. Two weeks after Satyam's collapse, the SEBI made it mandatory for controlling shareholders to disclose any share pledges.

(c) Increased Financial Accounting Disclosures: The SEBI also recently proposed requiring companies to disclose their balance sheet positions twice a year. Pre-Satyam, the regulations only required disclosure of balance sheet positions once a year. The increased reporting of companies' balance sheets will provide investors with more information on the stability of a company's financial position. Increasing both the frequency and detail of disclosure will help provide for a more robust market check-e.g. investors will be able to police companies better and pay more attention to accounting irregularities. For example, increased frequency of disclosure of Satyam's balance sheet could have led to an investor discovering, and pressing the board to investigate, the claimed large cash deposits in non-interest bearing accounts more quickly.

(d) IFRS (Adoption of International Standards): Satyam strengthened India's commitment to adopting International Financial Reporting Standards (IFRS) by 2011. Currently, Indian Generally Accepted Accounting Practices (GAAP) and the IFRS differ significantly. Globally, more and more countries are moving towards IFRS, as currently more than 100 countries require, permit, or are converting to IFRS. Adopting IFRS will facilitate investor comparisons of financial performance across country lines and will increase confidence in the accounting numbers. 
(e) Creation of New Corporate Code by the Ministry of Corporate Affairs: In addition to the new SEBI regulatory requirements, the Indian Ministry of Corporate Affairs (MCA) is drafting a new corporate code for Indian publicly listed companies. The new code will apply along with the regulatory obligations imposed by the SEBI. Adherence to the Code will be voluntary; however, every company that deviates from the codes requirements must disclose the deviations to the ministry. The MCA anticipates that the new code will impose more stringent disclosure obligations than the SEBI currently requires.

Satyam grossly violated all rules of corporate governance (Chakrabarti, 2008). The Satyam scam had been the example for following "poor" CG practices. It had failed to show good relation with the shareholders and employees. As Kahn (2009) stated, "CG issue at Satyam arose because of nonfulfillment of obligation of the company towards the various stakeholders. Of specific interest are the following: distinguishing the roles of board and management; separation of the roles of the CEO and chairman; appointment to the board; directors and executive compensation; protection of shareholders rights and their executives." In fact, shareholders never had the opportunity to give their consent prior to the announcement of the Matyas deal and 'falsified' documents with grossly 'inflated' financial reports were delivered to them. Ultimately, shareholders were at a loss and felt cheated. Surely, questions about management's credibility were raised, in addition to the non-payment of advance taxes to the government. Together, these issues raise questions about Satyam's financial health. According to Sharma (2015), "Some of the steps which could be taken to strengthen corporate governance are: have in all listed companies a code on ethics; independent regulatory body on the lines of the Public Company Accounting Oversight Board (PCAOB) of USA; rotation of external auditors in non-financial institutions; Reform Audit Education; split offices of chairman and CEO; encourage competent directors; abolish practice of nominating independent directors, exempt independent directors from vicarious liability; provide insurance cover to them; review the definition of independent director given in clause 49 of listing agreement; close supervision of rating agencies; superior Board practices, improve remuneration policy; legislative sanction to insider trading laws; introduce new audit standards; make audit committee strictly independent; prohibit political funding; install whistle-blower system; introduce class action suit \& compensation; make CSR compliance a mandatory provision; have in place permanent PPP system, and enhance criminal and civil penalties."

The 2009 Satyam scandal in India highlighted the nefarious potential of an improperly governed corporate leader. As the fallout continues, and the effects were felt throughout the global economy, the prevailing hope is that some good can come from the scandal in terms of lessons learned (Behan, 2009). Here are some lessons learned from the Satyam Scandal:

- Investigate All Inaccuracies: The fraud scheme at Satyam started very small, eventually growing into $\$ 276$ million white-elephant in the room. Indeed, a lot of fraud schemes initially start out small, with the perpetrator thinking that small changes here and there would not make a big difference, and is less likely to be detected. This sends a message to a lot of companies: if your accounts are not balancing, or if something seems inaccurate (even just a tiny bit), it is worth investigating. Dividing responsibilities across a team of people makes it easier to detect irregularities or misappropriated funds.

- Ruined reputations: Fraud does not just look bad on a company; it looks bad on the whole industry and a country. "India's biggest corporate scandal in memory threatens future foreign investment flows into Asia's third-largest economy and casts a cloud over growth in its oncebooming outsourcing sector. The news sent Indian equity markets into a tail-spin, with Bombay's main benchmark index tumbling $7.3 \%$ and the Indian rupee fell" (IMF, 2010). Now, because of the Satyam scandal, Indian rivals will come under greater scrutiny by the regulators, investors and customers.

- Corporate Governance needs to be stronger: The Satyam case is just another example supporting the need for stronger CG (Bhasin, 2011). All public-companies must be careful when selecting executives and top-level managers. These are the people who set the tone for the company: if there is corruption at the top, it is bound to trickle-down. Also, separate the role of CEO and Chairman of the Board. Splitting up the roles, thus, helps avoid situations like the one at Satyam. 
The Satyam Computer Services' scandal brought to light the importance of ethics and its relevance to corporate culture. The fraud committed by the founders of Satyam is a testament to the fact that "the science of conduct" is swayed in large by human greed, ambition, and hunger for power, money, fame and glory. Scandals from Enron to the recent financial crisis have time and time again proven that there is a need for good conduct based on strong ethics. Not surprising, such frauds can happen, at any time, all over the world. Satyam fraud spurred the government of India to tighten CG norms to prevent recurrence of similar frauds in the near future. The government took prompt actions to protect the interest of the investors and safeguard the credibility of India and the nation's image across the world.

\subsection{CONCLUSION}

It is widely accepted that corporate entities of all sizes across the world are susceptible to accounting scandals and frauds. Undoubtedly, various types of frauds and scams reduced the creditability of financial information that investors use in making decisions. From Enron and WorldCom in 2001 to Madoff and Satyam in 2009, accounting fraud has been a dominate news item in the past decade. Perhaps, no financial fraud had a greater impact on accounting and auditing profession than Enron, WorldCom, and recently, India's Enron: "Satyam". Unlike Enron, which sank due to "agency" problem, Satyam was brought to its knee due to "tunneling". But it may be that the greatest impact of Enron and WorldCom was in the significant increased focus and awareness related to fraud. As Bhasin stated (2016), "Forensic accounting skills are becoming increasingly relied upon within a corporate reporting system that emphasizes its accountability and responsibility to stakeholders."

The unfolding Satyam sage, India's Enron, has been a watershed event in Indian corporate history. According to the founder's own public confession, Satyam had inflated its reported revenues by $25 \%$, its operating margins by over 10 times, and its cash and bank balance by over 1 billion dollars. The magnitude of this fraud makes it by far the biggest accounting scandal in India's history (Ingram, 2015). The Satyam scandal highlights the importance of securities laws and CG in emerging markets (Bhasin, 2015). There is a broad consensus that emerging market countries must strive to create a regulatory environment in their securities markets that fosters effective CG. India has managed its transition into a global economy well, and although it suffers from CG issues, it is not alone as both developed countries and emerging countries experience accounting and CG scandals. The Satyam scandal brought to light, once again, the importance of ethics and its relevance to corporate culture (Bhasin, 2013, a). The fraud committed by the founders of Satyam is a testament to the fact that "the science of conduct is swayed in large by human greed, ambition, and hunger for power, money, fame and glory" (Chen, 2010)

All kind of scandals/frauds have proven that there is a need for good conduct based on strong ethics. The Indian government, in Satyam case, took very quick actions to protect the interest of the investors, safeguard the credibility of India, and the nation's image across the world. Moreover, Satyam fraud has forced the government to re-write CG rules and tightened the norms for auditors and accountants (Bhasin, 2013b). The Indian affiliate of PwC "routinely failed to follow the most basic audit procedures. The SEC and the PCAOB fined the affiliate, PwC India, \$7.5 million in what was described as the largest American penalty ever against a foreign accounting firm" (Norris, 2011). According to Mr. Chopra, President, ICAI (January 25, 2011), "The Satyam scam was not an accounting or auditing failure, but one of CG. This apex body had found the two PWC auditors prima-facie guilty of professional misconduct." The $\mathrm{CBI}$, which investigated the Satyam fraud case, also charged the two auditors with "complicity in the commission of the fraud by consciously overlooking the accounting irregularities".

The Satyam fraud has shattered the dreams of different categories of investors, shocked the government and regulators alike and led to questioning the accounting practices of statutory auditors and CG norms in India (Bhasin, 2015a, 2016a). The auditor is paid to ask questions; in this case it seems to have been paid not to ask any. The company could not have hoodwinked the investors without the auditor being on its side. This was no complicated accounting fraud like Enron was. The culture at Satyam, especially dominated by the board, symbolized an unethical culture. On one hand, his rise to stardom in the corporate world, coupled with immense pressure to impress investors, made Mr. Raju a "compelled 
leader to deliver outstanding results." On the contrary, Mr. Raju had to suppress his own morals and values in favor of the greater good of the company. The board connived with his actions and stood as a blind spectator; the lure of big compensation to members further encouraged such behavior. But, in the end, truth is sought and those violating the legal, ethical, and societal norms are taken to task as per process of law. The public confession of fraud by Mr. Ramalinga Raju speaks of integrity still left in him as an individual. His acceptance of guilt and blame for the whole fiasco shows a bright spot of an otherwise "tampered" character. So, while Raju ran his fraud, the auditor slept, the analysts slept and so did the media. To be fair, the media did an excellent job of exposing Raju and his many other 'shenanigans' after he had confessed (Kaul, 2015). Now more than six years later, the first decision in the Satyam scam has been made. Of course, we haven't seen the last of this case, given the slow pace at which our judicial system works.

The fraud finally had to end and the implications were having far reaching consequences. Thus, Satyam scam was not an accounting or auditing failure, but one of CG. Some of the prominent issues, according to Sharma (2015), were: unethical conduct, insider trading, false books and bogus accounting, lax board, unconvinced role of independent directors, questionable role of the audit committee, dubious role of rating agencies, questionable role of banks, false disclosures, no action on whistle blowers' information, promoters pledging of shares, etc. Undoubtedly, the government of India took prompt actions to protect the interest of the investors and safeguard the credibility of India and the nation's image across the world. With all the 10 people involved in the multi-crore accounting fraud in the erstwhile Satyam Computer Services Ltd (SCSL) found guilty by a special Central Bureau of Investigation court in Hyderabad, the six-year-old case has reached its logical conclusion. A special court in Hyderabad found all the ten accused in the Satyam scam guilty of cheating, forgery, destruction of evidence and criminal breach of trust. This includes the founder and the Chairman of the company B Ramalinga Raju. The court pronounced a seven year-jail term for the founder and also imposed a Rs. 5 crore fine on Raju. The decision came more than six years after the scam first came to light in 2009.

It is good to see that the Satyam case is different at least in one respect-we now have all the details about the modus operandi of the fraud. In its recent indictment of the former promoters and top managers of Satyam, the Securities and Exchange Board of India (SEBI) has provided minute and fascinating details about how India's largest corporate scam was committed. But SEBl's account also reveals how stupendously easy it is to pull off financial fraud on a grand scale, even in publicly listed companies. Perpetrators often manage to evade the long-arm of the law. When they are brought to book, the actual details of the crime get lost in legal technicalities. And untangling the mess usually takes such a long time that, by the time the wrongdoer is hauled up, most people have forgotten what the crime was all about. With the legacy of the British legal system, India has one of the best CG laws but poor implementation together with socialistic policies of the pre-reform era has affected CG. Concentrated ownership of shares, pyramiding and tunneling of funds among group companies mark the Indian corporate landscape (Ahmad, et al., 2010). Boards of directors have frequently been silent spectators with the DFI nominee directors unable or unwilling to carry out their monitoring functions. Since liberalization, however, serious efforts have been directed at overhauling the system with the SEBI instituting the Clause 49 of the Listing Agreements dealing with CG. In addition, the CG framework needs to be strengthened, implemented both in "letter as well as in right spirit," and enforced vigorously to curb white-collar crimes.

\section{REFERENCES}

ACFE (2010), "Report to the Nation on Occupational fraud and abuse," The Association of Certified Fraud Examiners, available at

American Institute of Certified Public Accountants (2002), "SAP-99: Consideration of Fraud in a Financial

Statement Audit," Auditing Standard Board, AICPA, available at http://www.aicpa.org/info/sarbanes_oxley_summary.html. 
Agrawal, S. and Sharma, R. (2009), "Beat this: Satyam won awards for corporate governance, internal audit." vcCircle. Available at www.vccircle.com/news.

Ahmad, T., Malawat, T., Kochar, Y. and Roy, A. (2010), "Satyam Scam in the Contemporary corporate world: A case study in Indian Perspective," IUP Journal. Available at SSRN,1-48.

Behan, B. (2009), "Governance lessons from India's Satyam," Business Week, 16 January.

Basilico, E., Grove, H, and Patelli, L. (2012), "Asia's Enron: Satyam (Sanskrit word for truth)," Journal of Forensic \& Investigative Accounting, 4(2), 142-160.

Beirstaker, J.L., Brody, R.G. and Pacini, C. (2005) “Accountants' perceptions regarding fraud detection and prevention methods", Managerial Auditing Journal, 21(5), 520-535.

Bhasin, M.L. (2008), "Corporate Governance and Role of the Forensic Accountant, The Chartered Secretary Journal, Vol. 38(10), October, 1361-1368.

Bhasin, M.L. (2011), Corporate Governance Disclosure Practices: The Portrait of a Developing Country, International Review of Business Research Papers, 7(1), January, 393-419.

Bhasin, M.L. (2013), Corporate Accounting Scandal at Satyam: A Case Study of India's Enron, European Journal of Business and Social Sciences, 1(12), March, 25-47.

Bhasin, M.L. (2013a), Corporate Accounting Fraud: A Case Study of Satyam Computer Limited, Open Journal of Accounting, April, 2(2), 26-38.

Bhasin, M.L. (2013b), Corporate Governance and Role of the Forensic Accountants: An Exploratory Study of an Asian Country, International Journal of Contemporary Business Studies, 4(7), July, 38-59.

Bhasin, M.L. (2015), Menace of Frauds in Banking Industry: Experience of a Developing Country, Australian Journal of Business and Management Research, 4(12), April, 21-33.

Bhasin, M.L. (2015a), Creative Accounting Practices in the Indian Corporate Sector: An Empirical Study, International Journal of Management Science and Business Research, Volume 4, Issue 10, October 2015, E-ISSN 2226-8235 published by QS publishers, USA, pp. 35-52 (USA).

Bhasin, M.L. (2016), Contribution of Forensic Accounting to Corporate Governance: An Exploratory Study of an Asian Country, International Business Management Journal, 10(4), 479-492.

Bhasin, M.L. (2016a), Survey of Creative Accounting Practices: An Empirical Study, Wulfenia Journal KLAGENFURT, 23(1), January, 143-162,

Bologna, G.J. and Lindquist (1996), "Fraud Auditing and Forensic Accounting: New Tools and Techniques," Wiley \& Sons, New Jersey.

Bowen, R.M., Call, A.C and Rajgopal, S. (2010), "Whistle-blowing: target firm characteristics and economic consequences," The Accounting Review, 85(4)1239-1271.

Blakely, R. (2009). "Investors raise questions over PWC Satyam audit," Times Online.

Calderon, T. G., and B. P. Green. (1994). "Signaling Fraud by Using Analytical Procedures," Ohio CPA Journal, April, 27-38.

Cecchini, M., Aytug, H., Koehler, G.J. and Pathak, P. (2010), "Detecting management fraud in public companies," Management Science, 56(7) July, 1146-1160.

Crutchley, C.E., Jensen, M.R.H., and Marshall (2007), "Climate for scandal: corporate environments that contribute to accounting fraud," The Financial Review, 42, The Eastern Finance Association, pp.5373.

Chen, S. (2010) "The role of ethical leadership versus institutional constraints: a simulation study of financial misreporting by CEOs," Journal of Business Ethics, Springer, 93(2), 33-52.

Cheng, S.S., Padgett, D.R. and Parekh, V. (2013), Crisis Response across borders: a comparative study of two companies' image repair discourse, International Journal of Business and Social Science, 4(5), May 124-140.

Chakrabarti, R., Megginson, W., Yadav \& Pradeep K. (2008). Corporate Governance in India. Journal of Applied Corporate Finance, 20(1), 59.

Chopra, A. (2011), "Satyam fraud, not an accounting failure," Business Standard, 25 January. Available at http://www.business-standard.com.

Choo, F. and Tan, K. (2007) 'An "American Dream” Theory of Corporate Executive Fraud', Accounting Forum, Issue 31: 203-215.

COSO (2010), "Fraudulent financial reporting: 1987-2007," Committee of Sponsoring Organizations of the Treadway Commission, available at http://www.coso.org.

D’Monte, L. (2008). Satyam: just what went wrong? Rediff India Abroad. 
Dagar, S.S. (2009). How Satyam was sold The untold story: How the IT services major was rescued against all odds.Business Today, July.

Damodaran, M. (2009), "Listed firms to get new conduct code," Financial Chronicle, available at http://wrd.mydigitalfc.com.

Deloitte Forensic Center (2011), "Fraud, Bribery and Corruption Practices Survey," available at http://www.deloitte.com.

Dixit, N. (2009), What Happened at Satyam? March 1, available at Wharton@knowledge.com

Fernando, A.C. (2010), Satyam: Anything but Satyam, Loyala Institute of Business Administration. Available at www.publishingindia.com.

Haugen, S. and Selin, J.R. (1999) "Identifying and controlling computer crime and employee fraud", Industrial Management \& Data Systems, 99(8),340-344.

Hindustan Times (2015), "Satyam Scam: All you need to know about India's biggest accounting fraud," April 9.

Hogan, C.E., Razaee, Z, Riley, R.A. and Velury, U.K. (2008), "Financial statement fraud: insights from the academic literature," Auditing: A Journal of Practice \& Theory, 27(2), November, 231-252.

ICAI (2009). ICIA finds ex Satyam CFO, Price Waterhouse auditors guilty. Outlook India.com.

Ingam, K. (2015), India's Satyam Scandal: A Blessing in Disguise? 20 Dec. Recorder Press.

Jeffords, R. (1999), “How useful are the Treadway risk factors?”, Internal Auditor, 49(2) June.

Kahn, J. (2009). The Crisis exposes all the flaws. Newsweek.

Kaul, V. (2015), Satyam scam: Ramalinga Raju, the man who knew too much, gets 7 years in jail, April 10.

Khedekar, D. (2010), Corporate Crime: a comparison of culture at Enron and Satyam, Economics \& Business Journal: Inquiries and Perspectives, 3(1) Oct. 156-175.

Kripalani, M. (2009). India's Madoff Satyam scandal rocks outsourcing industry. Business Week.

KPMG Fraud Survey 2009, 2003, 1998, 1994. Available at www.kpmginstiutes.com.

Krishnan, A. (2014), Finally, the truth about Satyam, The Hindu Business Line, July 18.

Manoharan, T.N. (2011), "Financial Statement Fraud and Corporate Governance," 11 November. Available at www.slideserve.com.

Miller, G.S. (2006), "The press as a watchdog for accounting fraud," Journal of Accounting Research, 44(5), December, 1001-1033.

Norris, F. (2011), “Indian Accounting Firm is Fined \$7.5 million over fraud at Satyam," The New York Times, April 5, 2011.

Niazi, A. and Ali, M. (2015), The Debacle of Satyam Computers Ltd.: A Case Study from Management's Perspective, Universal Journal of Industrial and Business Management, 3(2), 58-65.

PricewaterhouseCoopers (PwC, 2007), "Global Economic Crime Survey." Available at: http://www.pwc.com.

Ramachadran, S. (2009). Raju brings down Satyam, shakes India. Asia Times Online Ltd.

Rezaee, Z. (2005). Causes, consequences, and deterrence of financial statement fraud. Critical Perspectives on Accounting, 16(3), 277-298.

SFIO Report published in the Pioneer (New Delhi), May 4, 2009, p 10

Schrand and Zechman (2007), "Executive overconfidence and the slippery road to fraud," http://faculty.chicagobooth.edu.

Sharma, S. and Brahma (2000), "A Role of Insider in banking Fraud," available at http;// manuputra .com.

Sharma, J.P. (2015), What went wrong with Satyam? Paper presented at WCFCG Global Convention, in association with Institute of Directors, available at www.

Shirur, S. (2011), "Tunneling vs agency effect: a case study of Enron and Satyam," Vikalpa, 36(3), JulySeptember, 9-20.

Shubhashish (2015), "All that you need to know about the Satyam Scam," DNA, April 9.

Smith, E. R. (1995). A positive approach to dealing with embezzlement. The White Paper, August/September, 17-18.

The Hindu (2015), Satyam Scandal: Who, what and when? May 11.

Telberg, R. "Credibility Crisis Needs Global Curve," Al Large, August 11, 2003, www.cpazbis.com

Timmons, H. and Wassener, B. (2009), "Satyam chief admits huge fraud," January 8, New York Times Online, available at www.nytimes.com. 
Vasudev, P.M. (2010), Satyam and Enron: A Tale of two companies and two countries, Sept. 14, Deccan Herald, available at http://www.deccanherald.com/content/96271/satyam-amp-enron-tale-two.html.

Willison, R. (2006) "Understanding the offender/environment dynamic for computer crimes", Information Technology \& People, 19(2), 170 - 186

Winkler, D. India's Satyam Accounting Scandal, February 1, 2010, The University of lowa Center for International Finance and Development. Available online at http://blogs.law.uiowa.edu.

Wharton (2009), Scandal at Satyam: Truth, Lies and Corporate Governance, available at knowledge@wharton.

Ziegenfuss, D.E. (1996) "State and local government fraud survey for 1995”, Managerial Auditing Journal, 11(9), 50-55. 